\title{
Analyzing Persuasive Strategies Used in e-Brochures
}

\author{
Difiani Apriyanti*, Sumira \\ English Department \\ Politeknik Negeri Padang \\ Padang, Indonesia \\ *difi.apriyanti@gmail.com, sumiradoano@gmail.com
}

\begin{abstract}
This research aims to analyze persuasive strategies used by the students of the English Department of Politeknik Negeri Padang (PNP) in creating e-Brochures. Ten brochures are chosen in this qualitative descriptive research. The data are the persuasion strategies applied in the brochures. After analyzing descriptively using Aristotle's rhetorical 'proof; ethos, logos, and pathos are found in the brochures. It is interesting to see that these brochures which talk about the natural view as the tourism destination tend to have some combination of persuasive strategies. It is implied that to create a good brochure, the writer has to consider the norm and value, then convince the reader with some argument or reason, and show his/her feeling about the object of the brochure.
\end{abstract}

Keywords—persuasive writing, brochure, promotion

\section{INTRODUCTION}

At the end of 2019, people all over the world were shocked by the news that broadcast suffered people in Wuhan China. No more news shows about parties or events of welcoming the New Year 2020. People all over the world became the witness on how the virus which is known as Covid-19 attacked people anywhere and anytime. The virus spread quickly and make people panic, and the world announced it as a pandemic. Since the vaccine has not been found yet, people are trying hard to prevent it. The health protocols are announced. Besides strengthening body immunity, using a mask, washing hands, people are asked to do the social distance. Therefore, some nations directly applied lockdown.

Meanwhile in Indonesia, it is known PSBB (Pembatasan Sosial Berskala Besar). As a developing county, this regulation has created a big collapsed in all sectors of life. Tourism has been the worst affected of all major economic sectors. After PSBB was taken off by the government, tourist industries are struggling to stand on their feet again and it gives hard times for Indonesia economy. As Hassan [1] said that the largest global economic sector is tourism and its importance is rising.

The research by Qiu et al. [2] said that suggestions offerered during post-pandemic recovery actions must be done through cooperation between local authorities and tourism organizations. Milman and Pizam [3] from his research also mentioned the relationship of support to tourism with the residents' perceptions of the consequences of tourism.
It can be said that in a crisis condition, people where the tourist destination located have a big role in supporting the place. Therefore, the English Department of Politeknik Negeri Padang (PNP) leads their students to create promotion brochures which are e-brochure for tourist destinations of West Sumatra which is most are nature tourisms. This is an act of support from Minangkabau (the name of the tribe of West Sumatra) especially to nature tourist destinations. Brochure is chosen since it is a media that can make people calm and encourage them in postive actionwhen reading it [4]. Thus, it is hoped that people are willing to read the brochure and will know and interested on the place. Brito and Pratas [5] mentioned that one of the mediums for tourism advertising is a brochure since it is versatile and ubiquitous.

In writing a brochure that is intended to convince readers to believe in an idea or opinion and to do an action, a set of strategies for persuasion is needed. Logos, pathos, and ethos are the strategy of persuasion [6,7] that can be applied in writing the brochure. It is known as Aristotle's rhetorical 'proofs'. From the definition, logos is an argument or reason used by a writer to convince the reader about his/or opinion. Pathos is passion and feeling which commit to what is being said and done by the writer. Ethos is the character or the reputation and experience of the writer, which makes readers trust what he or she conveyed [8]. Higgins and Walker [7] classify Logos into some categories. They are argumentation, logic, warrants or justification, claims, data, and evidence, or example. While pathos can be classified into metaphors and identification especially through cultural references such as hope, aspiration, loyalty, sympathy, and friendship. While Ethos, it has some classification as similitude, ingratiation, deference, expertise, self-criticism, an inclination to succeed, and consistency.

The brochures made by the English Department of West Sumatra were e-Brochures that support the promotion of nature tourism for its beautiful scenery and view include hills, canyon, cave, see and many more. The brochures will be given directly to the target or users like Banto Royo Agam, Tiger Camp Lubuk Minturun, Konservasi Penyu Pasir Jambak, Miniatur Makkah Lubuk Minturun, Goa Batu Kapal, Desa Kubu Gadang, and many more.

It is interesting to see how the students developed their ebrochure to promote the tourist destinations in West Sumatra in 
this pandemic situation. Therefore, this research was conducted to analyse persuasion strategies applied by the students in promoting tourist destinations which are nature tourists.

\section{METHODS}

This research was called as descriptive qualitative. This method was chosen since it is a very common procedure for researching many disciplines, including social sciences [9]. Ten brochures created by students of English Department PNP used to reveal evidence of Aristotle's rhetorical appeals to ethos, logos, and pathos. The brochures were about tourist destinations specifically nature tourism in West Sumatra Indonesia. The brochures were then analysed by categorizing it into the type of each strategy. First, each brochure was read paragraph by paragraph. Second, the persuasion strategies and persuasive techniques used were identified for each paragraph. Then it was described qualitatively become the result of this research.

\section{RESULTS AND DISCUSSION}

There were ten e-Brochures created by students of the English Department Politeknik Negeri Padang. The brochures were aimed to promote the tourist destinations in West Sumatra. All of the tourist destinations written in the brochures are nature tourism. The brochures will be given to the users and they will upload it on their website.

After analyzing the ten brochures, it is found that the writer chose Aristotle's rhetorical 'proof. There are logos, pathos, and ethos in the brochures. The table 1 below shows the samples.

TABLE I.

BROCHURE ANALYSIS

\begin{tabular}{|l|l|}
\hline \multicolumn{1}{|c|}{ Quotation from the Brochure } & $\begin{array}{c}\text { Persuasion } \\
\text { Strategies }\end{array}$ \\
\hline $\begin{array}{l}\text { 1. The tiger camp has a natural swimming pool filled with } \\
\text { mountain spring. Along with the pool, some trees make the } \\
\text { atmosphere cool, and the color on the tree trunk makes it beautiful. } \\
\text { This pool is suitable for tennagers and adults to spend their } \\
\text { holiday }\end{array}$ & Logos \\
\hline $\begin{array}{l}\text { 2. The arena of the game is a wooden bridge that is about 5 meters } \\
\text { high from the ground. This wooden bridge is located at the top of } \\
\text { the Tiger Camp area, precisely near the panorama. Visitors can } \\
\text { play in this area while enjoying a beautiful panorama from a heigh }\end{array}$ & Logos \\
\hline $\begin{array}{l}\text { 3. Tiger camp opens every day from 8 am to 6.30 pm. The } \\
\text { entrance ticket is IDR 10.000,- On Sunday and national holidays, } \\
\text { the entrance fee is IDR 15.000,- and there is live music } \\
\text { performance for the visitors. You will enjoy your weekends and } \\
\text { holidays. }\end{array}$ & Logos \\
\hline $\begin{array}{l}\text { 4. If you are interested in visiting, you can use private vehicles via } \\
\text { Padang City bypass, heading to Lubuk Minturun. It only takes } \\
\text { about 30 minutes from the city center and Minangkabau Airport. }\end{array}$ & Ethos \\
$\begin{array}{l}\text { You can also take the yellow public transportation, which goes to } \\
\text { the Lubuk Minturun route }\end{array}$ & \\
\hline $\begin{array}{l}\text { 5. It is so interesting to see the process of collecting the turtle eggs } \\
\text { which can be done in the morning, afternoon, or at night }\end{array}$ & Ethos \\
\hline $\begin{array}{l}\text { 6. The main attraction of Banto Royo is a wooden bridge that is } \\
\text { made around the lake, so you can walk on it comfortably }\end{array}$ & Ethos \\
\hline $\begin{array}{l}\text { 7. Goa Batu has a unique wall. Actually, the color of Goa Batu } \\
\text { Kapal is green, but it will be colorful and beautiful when the sun } \\
\text { reflects light on it. }\end{array}$ & Pathos \\
\hline $\begin{array}{l}\text { 8. The two parts have a small river in the middle that makes the } \\
\text { cave looks more beautiful. The cave is formed naturally by nature }\end{array}$ & Pathos \\
\hline
\end{tabular}

In applying logos, pathos, and ethos, the writer used different kinds of persuasive techniques. Seven persuasive techniques are applied in all of the ten brochures.

First, the writers used logos persuasion strategy and examples of persuasive techniques. This can be seen in the first sample. The writer brings the readers into his examples of the Tiger Camp pool by telling that the pool is natural, filled with mountain spring, surrounded by trees, cool atmosphere, and has colorful shadow from the tree trunk. He gave examples of how the pool looks like and in the end said that the pool is a suitable place for a holiday. By giving a conclusion, it means that the writer used Reasoning from Specific Instances. Lucas [6] said that that reasoning can be made from specific instances. It goes from particular facts to a general conclusion. Specific instances are given and then a general conclusion is made.

Second, the writers used logos persuasion strategy and argumentation persuasive technique. This can be seen in the second sample. The writer brought his readers to his argumentation about the wooden bridge by saying that the wooden bridge 5 meters high from the ground, on the top of the Tiger Camp area, and near the panorama. Then the writer said that the wooden bridge is a fun arena game. Here, the writer was using causal reasoning. Lucas [6] said that reasoning can be made by establishing a relationship among the events or known as Causal Reasoning.

Third, the writers used logos persuasion strategies and data persuasive techniques. He gives complete data about the open hours, day off, the ticket fee, and also extra facilities provided there. This can be seen in the third sample. The writer gave data that Tiger Camp opens from 8 am to $6.30 \mathrm{pm}$. The writer also gave the data about the price of the entry ticket on weekdays and weekends and national holidays. The data about what the visitors will get on the weekends. The writer emphasizes that the expensive ticket on weekdays is because the visitors are going to be entertained.

Fourth, the writers used ethos persuasion strategies and experience persuasive techniques. The writer brings the readers to his experience when visiting the place. They shared about the transportation means that can be used to reach the place, the distance of the place, and how is the condition of the route. $\mathrm{He}$ mentioned how to go there with private transportation like cars and motorcycle and public transportation such as buses. This is seen in the sample number four. In the sample, the writer told about his experience visiting the place more emphasizing his experience using public transportation.

Fifth, the writers used the ethos persuasion strategy and value persuasive technique. He connected himself with value and delivered it to his reader. As seen in the fifth sample, the writer was telling the readers about the fertility of turtles. The writer hoped the writer the readers will get knowledge especially in animal breeders and know how to take care of them. 
Sixth, the writers used ethos persuasion strategy and competence persuasive technique. Most of the writers want to show their readers the competency that they have. From sample number six, the writer was showing to the readers that the bridge is made from wood, and stepping on it will not hurt.

Seventh, writers used pathos persuasion strategies and positive feeling or emotion as the persuasive technique. In sample number seven, the writer brings the readers to an amazing feeling- a feeling that appears when a beautiful color reflected from the sun, just like when we see the rainbow after the rain.

Not only in sample number 7 , but in sample number 8 the writer also drives his readers to a feeling of amazed. He gave a beautiful description that makes the readers able to picture the beauty in their heads.

Everyone has their own way of interpreting signs, pictures, and clues, thus forming a mental image according to the objects observed [10]. Therefore, the ten brochures appeared different from interpretation. However, there are common things found in those brochures. It can be said that most of the brochures consist of Logos Persuasion Strategies using examples persuasive technique, logos persuasion strategy using data persuasive technique, using ethos persuasion strategy using experience persuasive technique, ethos persuasion strategy using value persuasive technique, ethos persuasion strategy using competence persuasive technique, and pathos persuasion technique using positive feeling or emotion. Moreover, the logos (reasoning ) were made with reasoning from specific instances and causal reasoning.

\section{CONCLUSION}

It can be concluded that the English Department Politeknik Negeri Padang students have successfully created brochures of promoting the nature tourism of West Sumatra by applying the persuasion strategies and persuasive technique. They are also able to make the logos (reason) in a good way that Lucas has proposed. It is also seen the similarity in the use of persuasive technique when telling objects which is quite the same. It is hoped that the following brochures will have more creativity by adding more persuasive techniques, and the students can increase more their competence in making logos (reason) following Lucas method.

\section{ACKNOWLEDGMENT}

We would like to thanks P3M PNP which has facilitated financially the researchers in conducting this research. The deepest gratitude is addressed to the Head of English Department Ms. Martini who always supports her staff especially in doing the research. We would also like to express appreciation to the students who collaborated with the research in serving the data. Finally, we would like to give special thanks to Ms. Lilimiwirdi, SS, M.Hum who validated the result of the data of this research.

\section{REFERENCES}

[1] H. Hassan, "The Representation of Malaysian Cultures in Tourism Brochures," Procedia - Soc. Behav. Sci., vol. 118, pp. 140-151, 2014.

[2] R.T.R. Qiu, J. Park, S.N. Li, and H. Song, "Social costs of tourism during the COVID-19 pandemic," Ann. Tour. Res., vol. 84, no. July, p. 102994,2020

[3] A. Milman and A. Pizam, "Social impacts of tourism on central florida," Ann. Tour. Res., vol. 15, no. 2, pp. 191-204, 1988

[4] Shalvee and S. Sambhav, "Role of mass media and communication during pandemic," Int. J. Creat. Res. Thoughts, vol. 8, no. 5, pp. 37861790, 2020

[5] P.Q. Brito and J. Pratas, "Tourism brochures: Linking message strategies, tactics and brand destination attributes," Tour. Manag., vol. 48, pp. 123-138, 2015.

[6] S.E. Lucas, The Art of Public Speaking, 10th ed. New York: McGrawHill, 2009.

[7] C. Higgins and R. Walker, "Ethos, logos, pathos: Strategies of persuasion in social/environmental reports," Account. Forum, vol. 36, no. 3, pp. 194-208, 2012.

[8] P. Thompson, Persuading Aristotle: The Timeless Art of Persuasion. Australia: Allen \& Unwin, 1998

[9] H. Nassaji, "Qualitative and descriptive research: Data type versus data analysis," Lang. Teach. Res., vol. 19, no. 2, pp. 129-132, 2015.

[10] D. Nimmo, Kominikasi Politik "Komunikator, Pesan, dan Media, 5th ed. Bandung: PT Remaja Rosdakarya, 2005. 